\title{
Hepatitis E Virus seroprevalence among cows in a rural area of southern Italy
}

\author{
Michela Pugliese ${ }^{1}$, Rocky La Maestra ${ }^{1 *}$, Annalisa Guercio ${ }^{2}$, \\ Giuseppa Purpari², Santina Di Bella ${ }^{2}$, Stefano Vullo ${ }^{2}$, and Pietro P. Niutta ${ }^{1}$ \\ ${ }^{I}$ Department of Veterinary Sciences - University of Messina, Mesina, Italy \\ ${ }^{2}$ Zooprophylactic Institute of Sicily “A. Mirri”, Palermo, Italy
}

PUGLIESE, M., R. LA MAESTRA, A. GUERCIO, G. PURPARI, S. DI BELLA, S. VULLO, P. P. NIUTTA:

Hepatitis E Virus seroprevalence among cows in a rural area of southern Italy. Vet. arhiv 91, 333-338, 2021.

\section{ABSTRACT}

Hepatitis E virus (HEV) is considered to be an emerging zoonotic disease, which causes numerous cases of hepatitis and deaths worldwide each year. Pigs are a host reservoir of HEV, but numerous other wild and domestic species can be infected. The aim of this study was to carry out serological screening of anti-HEV antibodies in cattle in the Sicily region (Southern Italy). Between April and December 2018, 231 serum samples were collected from cows and analysed with enzyme-linked immunosorbent assay (ELISA), for detection of HEV antibodies (IgG). The overall prevalence of anti-HEV antibodies was $36.36 \%(84 / 231 ; 95 \%$ CI 30-43). There were statistically significant differences in the HEV seroprevalence in animals of different ages ( $<11$ months: $11.41 \%$; $>12$ months: 39.30\%; $>24$ months: $54.10 \%)(\mathrm{P}<0.05)$. No statistically significant differences were detected between genders $(31.37 \%$ in male and $37.38 \%$ in female) $(\mathrm{P}>0.05)$. This study shows that further investigation of HEV in cattle is required to understand better the epidemiology in farm animals and the potential zoonotic risks for humans. This is the first report of HEV seroprevalence for cows in Italy, which provides baseline data for further studies and for control of HEV infection in cattle.

Key words: HEV; Hepatitis E Virus; antibodies; zoonosis; cow; ELISA

\section{Introduction}

Hepatitis $\mathrm{E}$ is a zoonosis caused by a positivesense, single stranded, non-enveloped RNA virus, belonging to the Hepeviridae family, genus Orthohepevirus, and species Orthohepevirus $A$ (SMITH et al., 2014). Orthohepevirus $A$ is classified into seven genotypes. Genotypes 1 and 2 are endemic in many developing countries in Asia, South America and Africa (PÉREZ-GRACIA et al., 2014; SAYED et al., 2015). They only affect humans and are associated with large epidemics due to poor hygienic conditions (REIN et al., 2012; KAMAR et al., 2017). Genotypes 3 and 4 are considered zoonotic (PÉREZ-GRACIA et al., 2014; SAYED et al., 2015) and can infect humans, pigs, rabbits, cows, deer and mongoose (SPAHR et al., 2018; XIA et al., 2015). Genotypes

\footnotetext{
*Corresponding author:

Rocky La Maestra, DVM Ph.D. candidate, Department of Veterinary Sciences - University of Messina, Mesina, Italy, Phone: +39 340823 9212; E-mail: rockylamaestra@gmail.com
} 
5 and 6 have been identified in wild boar, and are responsible for locally acquired infection in developed industrialized countries. Genotype 7 has been detected in camel (LEE et al., 2016). Transmission is mainly related to consumption of raw or undercooked meat from infected animals (COLSON et al., 2010). Transmission has also been documented by leafy green vegetables and field-grown strawberries irrigated by contaminated water and/or manure (BRASSARD et al., 2012; KOKKINOS et al., 2012). HEV is considered the major cause of viral hepatitis worldwide, that infects humans with animal reservoirs (PÉREZGRACIA et al., 2014). In recent years, an important increase has been observed in the incidence in Europe, suggesting there has been a change in the risk of acquiring the disease (KAMAR et al., 2017). Despite the fact that the infection is clinically silent in animals, in humans the clinical aspect varies from asymptomatic forms of acute hepatitis to severe liver disease, with higher hepatic and extra hepatic complications including renal and neurological disorders (DALTON et al., 2016), and liver failure in immunosuppressed patients (LENGGENHAGER and WEBER, 2017). Some studies suggest that HEV may be present in cow's milk and survive the pasteurization process (EMERSON et al., 2005; HUANG et al., 2016; LEE et al., 2016). The aim of this study was to analyze HEV prevalence in cows reared in rural areas of Southern Italy (Sicily) in order to evaluate whether cows should be considered an additional HEV reservoir.

\section{Materials and methods}

Ethics statement. The study was performed during the official sanitary routine inspection on farms when sampling of blood is usually included. All procedures were carried out in accordance with the standards recommended by the Guide for the Care and Use of Laboratory Animals, and Directive 2010/63/EU, and Italian and European rules on animal welfare. A form was given to the farmers to explain the procedures.

Animals. 231 adult mestizos (180 females/51 males) cows in good clinical condition, aged between two and five years, from 11 livestock farms located in the municipality of Messina (Sicily,
Southern Italy), were enrolled for the collection of blood samples, in the period of time from April 2018 to December 2018. The cattle were divided into three age groups:

Group 1: $<11$ months

Group 2: $>11<23$ months

Group 3: $>24$ months

Typically, each farm consisted of cows, goats, sheep, and pigs in variable numbers. Moreover, 4/11 farms examined offered 7 months (from $1^{\text {st }}$ of April to the $31^{\text {st }}$ of October) of daily pasture access with possible contact with wild boars. All farms were free from tuberculosis, brucellosis and leucosis.

Sample collection. All samples were collected from the jugular vein of the cattle and centrifuged at the laboratory of the Veterinary Teaching Hospital of the Department of Veterinary Sciences of Messina.

Serological tests. Sera were analyzed for the presence of IgG antibodies against HEV by the commercially available enzyme-linked immunosorbent assay (ELISA), developed by Wantai Biological Pharmacy (Beijing, China). All procedures were conducted in accordance with the manufacturer's instructions. The serum was diluted to $1: 10$ and incubated at 37 degrees for 30 minutes. The conjugate (peroxidase-labeled protein $\mathrm{A}$ ) was then added and incubated at $37^{\circ}$ for 30 minutes. Plates were washed and the substrate (100 $\mu \mathrm{L}$ of tetramethylbenzidine) was added. The reaction was then stopped after 15 minutes, and analysis by absorbance was then performed using a spectrophotometer. Values above +0.16 of absorbance were recorded positive for anti-HEV antibodies (GARCIA-HERNANDEZ et al., 2017).

Statistical analysis. All analysis were performed using a software package (Version 17.0, SPSS, Inc., Chicago, USA). Descriptive analysis was done for the study population. The prevalence of HEV seropositive was statistically analyzed by age and sex, using Fisher's exact test. The mean percentage of HEV-seropositive animals and confidence interval (CI) values were calculated using the binomial exact test. A P value $\leq 0.05$ was considered statistically significant. 


\section{Results}

There were 84 out of 231 (36.36\%; 95\% CI 3043) overall positive serum samples with anti-HEV IgG in the farmed cattle (Table 1). The highest seropositivity rate was detected in cows belonging to Group 2 (54.10\%; 95\% CI 44-64). No statistically significant difference in HEV seroprevalence was recorded between Groups 2 and $3(\mathrm{P}>0.05)$.
The seroprevalence of anti-HEV antibodies was statistically significantly different between Group 1 (11.41\%, 95\% CI 6-20) and Group 2 (39.30\%; 95\% CI 28-53) $(\mathrm{P}<0.04)$, and Groups 1 and $3(54.10 \%$; $95 \%$ CI 44-64) of farmed cows $(\mathrm{P}<0.01)$. A nonsignificantly higher seropositivity rate was detected in females $(37.78 \%$; 95\% CI 20-45) than in males (31.37\%, 95\%; CI 20-45).

Table 1. Prevalence of antibodies against HEV in cows examined, divided by age and gender

\begin{tabular}{|l|c|c|c|}
\hline Variable & HEV seropositive/total & Prevalence $\%$ & $95 \%$ CI for prevalence \\
\hline Group 1 (<11 months) & $9 / 79$ & 11.39 & $6-20$ \\
\hline Group 2 (>11 and $<23$ months) & $22 / 56$ & 39.28 & $28-53$ \\
\hline Group 3 (>24 months) & $53 / 96$ & 55.20 & $44-64$ \\
\hline TOTAL & $84 / 231$ & 36.36 & $30-43$ \\
\hline Males & $16 / 51$ & 31.37 & $20-45$ \\
\hline Females & $68 / 180$ & 37.77 & $31-45$ \\
\hline
\end{tabular}

\section{Discussion}

$\mathrm{HEV}$ is considered an emerging zoonotic disease in western countries due to the increase in cases of illness every year (ADLHOCH et al., 2016; CORNELIA et al., 2016). The World Health Organization (WHO) estimated the annual incidence of HEV infection is 20 million, leading to an estimated 3.3 million symptomatic cases of hepatitis E, with about 44,000 deaths in 2015 alone (WHO, 2019). It represents one of the five major human hepatotropic viruses, in addition to hepatitis A, B, C and $\mathrm{D}$ viruses. The mortality rate in healthy humans is generally low $(0.2-0.3 \%)$, but can rise to $20-30 \%$ in pregnant women, and in immunocompromised patients (HUANG et al., 2015). In Europe, HEV seroprevalence estimates in the general population range from $7.5 \%$ to $31.9 \%$, with the average rate being 19.16\% (MAUCERI et al., 2018). In Italy, HEV positivity varies widely between regions, from $49 \%$ in Abruzzo (an endemic region) to $0.4 \%$ in Molise. Sicily is in an intermediate position with $4.7 \%$ positivity. The epidemiology of HEV in Italy is however incomplete, as data are still lacking for some regions today (MAUCERI et al., 2018).

For many years, pigs have been considered the host reservoirs of HEV (SPAHR et al., 2018) but the cross-species infectivity of HEV has been well documented in cattle, sheep, and goats (DI MARTINO et al., 2016). HEV-specific antibodies have been found in breeds of domestic cattle (Bos taurus primigenius), such as yellow cattle (YAN et al., 2016), Holstein Frisian cattle (HUANG et al., 2016) and other dairy cattle (EL-TRAS et al., 2013) as well as in domesticated wild animals, such as yak (Bos grunniens), buffalo (Syncerus caffer) (EL-TRAS et al., 2013) or bison (Bison bison) (DONG et al., 2011). In northern and central Italy, HEV infection in animals has been demonstrated in domestic pigs (LA ROSA et al., 2016), wild boars (MAZZEI et al., 2015), rabbits (DI BARTOLO et al., 2016), wild deer (DI BARTOLO et al., 2017), and goats (DI MARTINO et al., 2016). In Sicily, HEV is found in $1.2 \%$ of shellfish, but still no epidemiological data exist for farm animals (PURPARI et al., 2018).

The prevalence of anti-HEV antibodies detected overall in Sicilian cows in the present study was $36.36 \%$, which was higher than in other countries, such as China $(14.87 \%)$ which is considered endemic for HEV (GENG et al., 2011; HUANG et al., 2002; SPAHR et al., 2018). It should be considered that in Sicily mixed farming is a common practice. Family-based, small-sized farms host many 
different domestic animals, including horses, cows, goats, sheep, pigs, chicken and ducks, which can be a suitable environment for cross-infection of HEV between pigs and cattle. This study also shows that the positivity with anti-HEV antibodies is greater with the increasing age of the enrolled cattle, up to a percentage of $54.1 \%$ in the adult cattle in group 3 . The higher seroprevalence detected in adults compared to young animals, can be explained by the fact that adult animals often graze outside the farm. Grazing provides the possibility of crossspecies HEV infection through cattle interactions with different types of domestic and, sometimes, wild animals such as boar or through contact with faeces from HEV infected animals (GENG et al., 2011; SPAHR et al., 2018).

This high seroprevalence rate suggests a possible zoonotic risk for humans (LIANG et al., 2014). In fact, it is important to consider that serological tests for diagnosis of HEV may give some false negatives, and therefore can lead to underdiagnoses. In an English study performed on human blood donors, a high rate of positives was detected by RT-PCR tests, while they were negative in serological tests (HEWITT et al., 2014). For now, HEV is not considered endemic in Sicily, but further studies should be focused on establishing the source of human HEV infections.

\section{Conclusion}

This study has two main limitations: the ELISA test used does not have a sensitivity comparable to direct virus detection techniques. In addition, the kit used is designed for humans, although it is also widely used in veterinary medicine. Other future developments could be HEV screening of milk, faeces and other animal secretions to investigate the actual transmission of the virus. Nevertheless, this present study showed the serological evidence of HEV in cattle farmed in Sicily (Southern Italy), which indicate the need for continued surveillance of HEV as a possible viral zoonosis. The data obtained may be considered a baseline for the strategic control and prevention of HEV in farms in Southern Italy.

\section{References}

ADlhoch, C., A. AVEllon, S. A. BAYlis, A. R. CICCAGLIONE, E. COUTURIER, R. DE SOUSA, J. EP`STEIN, S. ETHELBERG, M. FABER, Á. FEHÉR, S. IJAZ, H. LANGEL, Z. MAND'ÁKOVÁ, K. MELLOU, A MOZALEVSKIS, R. RIMHANEN-FINNE, V. RIZZI, B. SAID, L. SUNDQVIST, L. THORNTONS, M. E. TOSTI, W. VAN PELT, E. ASPINALL, D. DOMANOVIC, E. SEVERI, J. TAKKINEN, H. R. DALTON (2016): Hepatitis E virus: assessment of the epidemiological situation in humans in Europe, 2014/15. J. Clin. Virol. 82, 9-16.

DOI: 10.1016/j.jcv.2016.06.010

BRASSARD, J., M. J. GAGNE, M. GENEREUX, C. COTE (2012): Detection of human food-borne and zoonotic viruses on irrigated, field-grown strawberries. Appl. Environ. Microbiol. 78, 3763-3766.

DOI: 10.1128/AEM.00251-12

COLSON, P., P. BORENTAIN, B. QUEYRIAUX, M. KABA, V. MOAL, P. GALLIAN, L. HEYRIES, D. RAOULT, R. GEROLAMI (2010): Pig liver sausage as a source of hepatitis E virus transmission to humans. J. Infect. Dis. 202, 825-834.

DOI: $10.1086 / 655898$

CORNELIA, A., A. AVELlon, S. A. BAYlis, A. CICCAGLIONE, E. COUTURIER, R. DESOUSA, J. EPŠTEIN, S. ETHELBERG, M. FABER, A. FEHÉR, S. IJAZ, H. LANGE, Z. MANĎÁKOVÁ, K. MELLOU, A. MOZALEVSKIS, R. RIMHANEN-FINNE, V. RIZZI, B. SAID, L. SUNDQVIST, L. THORNTON, M. TOSTI, W. VAN PELT, E. ASPINALL, D. DOMANOVIC, E. SEVERI, J. TAKKINEN, H. DALTON (2016): Hepatitis E virus: assessment of the epidemiological situation in humans in Europe, 2014/15. J. Clin. Virol. 82, 9-16.

DOI: $10.1016 /$ j.jcv.2016.06.010

DALTON, H. R., N. KAMAR, J. J. VAN EIJK, B. N. MCLEAN, P. CINTAS, R. P. BENDALL, B.C. JACOBS (2016): Hepatitis E virus and neurological injury. Nat. Rev. Neurol. 12, 77-85.

DOI: $10.1038 /$ nrneurol.2015.234

DI BARTOLO, I., L. DE SABATO, A. MARATA, N. MARTINELLI, C. F. MAGISTRALI, M. MONINI, E. PONTIERO, F. OSTANELLO, F. M. RUGGERI ( 2016): Serological survey of hepatitis E virus infection in farmed and pet rabbits in Italy. Arch. Virol. 161, 1343-1346.

DOI: 10.1007/s00705-016-2778-y

Di BARTOlo, I., E. PONTERIO, G. ANGELONI, F. MORANDI, F. OSTANELLO, S. NICOLOSO, F. M. RUGGERI (2017): Presence of hepatitis E virus in a Red deer (Cervus elaphus) population in Central Italy. Transbound. Emerg. Dis. 64, 137-143.

DOI: $10.1111 /$ tbed.12353

DI MARTINO, B., F. DI PROFIO, I. MELEGARI, V. SARCHESE, S. ROBETTO, F. MARSILIO, V. 
MARTELLA (2016): Detection of hepatitis E virus (HEV) in goats. Virus Res. 225, 69-72.

DOI: $10.1016 /$ j.virusres.2016.09.008

DONG, C., J. MENG, X. DAI, J. H. LIANG, A. R. FEAGINS, X. J.MENG, N.M. BELFIORE, C. BRADFORD, J.L. CORN, C. CRAY, G.E. GLASS, M.L.GORDON, R.A. HESSE, D. L. MONTGOMERY, W. L. NICHOLSON, A. A. PILNY, S. RAMAMOORTHY, D. D. SHAVER, J. DROBENIUC, M. A. PURDY, H. A. FIELDS, S. C. KAMILI, G. TEO (2011): Restricted enzooticity of hepatitis E virus genotypes 1 to 4 in the United States. J. Clin. Microbiol. 49, 4164-4172.

DOI: $10.1128 /$ JCM.05481-11

EL-TRAS, W. F., A. A.TAYEL, N. N. EL-KADY (2013): Seroprevalence of hepatitis $\mathrm{E}$ virus in humans and geographically matched food animals in Egypt. Zoonoses Public Health 60, 244-251.

DOI: $10.1111 /$ j.1863-2378.2012.01516.x

EMERSON, S. U., V. A. ARANKALLE, R. H. PURCELL (2005): Thermal stability of hepatitis E virus. J. Infect. Dis. $192,930-933$.

DOI: $10.1086 / 432488$

GENG, J., L. WANG, X. WANG, H. FU, Q. BU, P. LIU, Y. ZHU, M. WANG, Y. SUI, H. ZHUANG (2011): Potential risk of zoonotic transmission from young swine to human: seroepidemiological and genetic characterization of hepatitis E virus in human and various animals in Beijing, China. J. Viral. Hepat. 18, 583-590.

DOI: $10.1111 /$ j.1365-2893.2011.01472.x

HEWITT, P. E., S. IJAZ, S. R. BRAILSFORD, R. BRETT, S. DICKS, B. HAYWOOD, I. T. R. KENNEDY, A. KITCHEN, P. PATEL, J. POH, K. RUSSEL, K. I. TETTMAR, J. TOSSEL, I. USCHIRO-LUMB, R.S. TEDDER (2014): Hepatitis E virus in blood components: a prevalence and transmission study in southeast England. The Lancet. 384: 1766-1773.

DOI: 10.1016/S0140-6736(14)61034-5

HUANG, F., Y. LI, W. YU, S. JING, J. WANG, F. LONG, C. YANG, Y. BI, W. CAO, C. LIU, X. HUA, Q. PAN (2016): Excretion of infectious hepatitis E virus into milk in cows imposes high risks of zoonosis. J. Hepatol. 64, 350-359.

DOI: $10.1002 /$ hep. 28668

HUANG, F., J. WANG, C. YANG, F. LONG, Y. LI, L. LI, S. JING, H. WANG (2015): Chinese pregnant women in their third trimester are more susceptible to HEV infection. Braz. J. Infect. Dis. 19, 672-674.

DOI: 10.1016/j.bjid.2015.08.009

HUANG, F. F., G. HAQSHENAS, D. K. GUENETTE, P. G. HALBUR, S. K. SCHOMMER, F. W. PIERSON, T. TOTH, X. MENG (2002): Detection by reverse transcription-PCR and genetic characterization of field isolates of swine hepatitis $\mathrm{E}$ virus from pigs in different geographic regions of the United States. J. Clin. Microbiol. 40, 1326-1332.

DOI: $10.1128 / J C M .40 .4 .1326-1332.2002$

KAMAR N., J. IZOPET, N. PAVIO, R. AGGARWAL, A. LABRIQUE, H. WEDEMEYER, H. R. DALTON (2017): Hepatitis E virus infection. Nat. Rev. Dis. Primers $16,17086$.

DOI: $10.1038 / \mathrm{nrdp} .2017 .86$

KOKKINOS, P., I. KOZYRA, S. LAZIC, M. BOUWKNEGT, S. RUTJES, K. WILlEMS, R. MOLONEY, A. M. DE RODA HUSMAN, A. KAUPKE, E. LEGAKI, M. D'AGOSTINO, N. COOK, A. RZEZUTKA, T. PETROVIC, A. VANTARAKIS (2012): Harmonised investigation of the occurrence of human enteric viruses in the leafy green vegetable supply chain in three European countries. Food Environ.Virol. 4, 179-191.

DOI: $10.1007 / \mathrm{s} 12560-012-9087-8$

LA ROSA, G., S. DELLA LIBERA, M. BRAMBILLA, C. BISAGLIA, G. PISANI, A.R. CICCAGLIONE, R. BRUNI, S. TAFFON, M. EQUESTRE, M. IACONELLI (2016): Hepatitis E virus (genotype 3) in slurry samples from swine farming activities in Italy. Food Environ. Virol. 9, 219-229.

DOI: $10.1007 / \mathrm{s} 12560-016-9270-4$

LEE, G. H., B. H. TAN, E. CHI-YUAN TEO, S. G. LIM, Y. Y. DAN, A. WEE (2016): Chronic infection with camelid hepatitis E virus in a liver transplant recipient who regularly consumes camel meat and milk. Gastroenterology 150, 355-357.

DOI: $10.1053 /$ j.gastro.2015.10.048

LENGGENHAGER, D., A. WEBER (2017): Hepatitis E Virus and the Liver: Clinical Settings and Liver Pathology. Gastroenterol. Clin. North. Am. 46, 393-407.

DOI: $10.1016 /$ j.gtc.2017.01.010

LIANG, H., S. SU, S. DENG, H. GU, F. JI, L. WANG, C. LIANG, H. WANG, G. ZHANG (2014): The prevalence of hepatitis $\mathrm{E}$ virus infections among swine, swine farmers and the general population in Guangdong Province, China. PLoS One 9: e88106.

DOI: 10.1371/journal.pone.0088106

MAUCERI, C., M. CLEMENTE, P. CASTIGLIA, R. ANTONUCCI, K. B. SCHWARZ (2018): Hepatitis E in Italy: A silent presence. J. Infect. Public Heal. 11, 1-8.

DOI: 10.1016/j.jiph.2017.08.004

MAZZEI, M., R. NARDINI, R. VERIN, M. FORZAN, A. POLI, F. TOLARI (2015): Serologic and molecular survey for hepatitis E virus in wild boar (Sus scrofa) in Central Italy. New Microbes New Infect 7, 41-47 DOI: 10.1016/j.nmni.2015.05.008

GARCIA-HERNANDEZ, M. E., M. CRUZ-RIVERA, J. I. SANCHEZ-BETANCOURT, O. RICO-CHAVEZ, A. VERGARA-CASTANEDA, M. E. TRUJILLO, R. E. SARMIENTO-SILVA (2017): Seroprevalence of anti- 
hepatitis $\mathrm{E}$ virus antibodies in domestic pigs in Mexico. BMC Vet. Res. 13, 289.

DOI: $10.1186 / \mathrm{s} 12917-017-1208-\mathrm{Z}$

PÉREZ-GRACIA, M. T., B. SUAY, M. L. MATEOSLINDEMANN (2014): Hepatitis E: an emerging disease. Infect. Genet. Evol. 22, 40-59.

DOI: 10.1016/j.meegid.2014.01.002

PURPARI, G., G. MACALUSO, S. DI BELLA, F. GUCCIARDI, F. MIRA, P. DI MARCO, A. LASTRA, E. PETERSEN, G. LA ROSA, A. GUERCIO (2018): Molecular characterization of human enteric viruses in food, water samples, and surface swabs in Sicily. Int. J. Infect. Dis. 80, 66-72.

DOI: $10.1016 /$ j.ijid.2018.12.011

REIN, D. B., G. A. STEVENS, J. THEAKER, J. S. WITTENBORN, S. T. WIERSMA (2012): The global burden of hepatitis E virus genotypes 1 and 2 in 2005 . Hepatology 55, 988-97.

DOI: $10.1002 / H E P .25505$

SAYED, I. M., A. S. VERCOUTER, S. F. ABDELWAHAB, K. VERCAUTEREN, P. MEULEMAN (2015): Is hepatitis $\mathrm{E}$ virus an emerging problem in industrialized countries? Hepatology 62, 1883-1892.

DOI: $10.1002 /$ hep. 27990
SMITH, D. B., P. SIMMONDS, International committee on taxonomy of viruses hepeviridae study group, S. JAMEEL, S. U. EMERSON, T. J. HARRISON, X.J. MENG, H. OKAMOTO, W.H. VAN DER POEL, M. A. PURDY (2014). Consensus proposals for classification of the family Hepeviridae. J. Gen. Virol. 95, 2223-2232.

DOI: 10.1099 /vir.0.068429-0

SPAHR, C., T. KNAUF-WITZENS, T. VAHLENKAMP, R. G. ULRICH, R. JOHNE (2018): Hepatitis E virus and related viruses in wild, domestic and zoo animals: A review. Zoonoses Public Health 65, 11-29.

DOI: 10.1111/zph.12405

WHO (2019): World Health Organisation Fact Sheet. https:// www.who.int/en/news-room/fact-sheets/detail/hepatitis-e

XIA, J., H. ZENG, L. LIU, Y. ZHANG, P. LIU, J. GENG, L. WANG, L. WANG, H. ZHUANG (2015): Swine and rabbits are the main reservoirs of hepatitis $E$ virus in China: detection of HEV RNA in feces of farmed and wild animals. Arch. Virol. 160, 2791-2798.

DOI: $10.1007 / \mathrm{s} 00705-015-2574-0$

YAN, B., L. ZHANG, L. GONG, J. LV, Y. FENG, J. LIU, L. SONG, Q. ZU, M. JIANG, A. XU (2016). Hepatitis E virus in Yellow Cattle, Shandong, Eastern China. Emerg. Infect. Dis. 22, 2211-2212.

DOI: $10.3201 /$ eid2212.160641

Received: 31 December 2019

Accepted: 29 July 2020

\section{PUGLIESE, M., R. LA MAESTRA, A. GUERCIO, G. PURPARI, S. DI BELLA, S. VULLO, P. P. NIUTTA: Seroprevalencija virusa hepatitisa $E$ u krava s ruralnih područja južne Italije. Vet. arhiv 91, 333-338, 2021. \\ SAŽETAK}

Virus hepatitisa E (HEV) smatra se emergentnom zoonozom koja uzrokuje brojne slučajeve hepatitisa i uginuća širom svijeta svake godine. Svinja je rezervoar HEV-a, no mogu se zaraziti i brojne druge divlje i domaće vrste. Cilj ovog istraživanja bio je provesti serološki probir anti-HEV protutijela u goveda na Siciliji (južna Italija). Od travnja do prosinca 2018. prikupljen je ukupno 231 uzorak seruma krava i analiziran testom ELISA za detekciju protutijela na HEV (IgG). Prevalencija anti-HEV protutijela bila je 36,36 \% (84/231; 95 \% CI 30 - 43). Pronađena je statistički znakovita razlika $(\mathrm{P}<0,05)$ u seroprevalenciji HEV-a u životinja različite dobi $(<11$ mjeseci: 11,41\%; $>12$ mjeseci: $39,30 \%$; > 24 mjeseci: 54,10 \%). Nije zabilježena statistički znakovita razlika $(\mathrm{P}>0,05)$ s obzirom na spol $(31,37$ \% u mužjaka i 37,38 \% u ženki). Rezultati ukazuju na potrebu daljnjih istraživanja HEV-a u goveda kako bi se bolje razumjela epidemiologija u farmskih životinja i potencijalan zoonotski rizik za ljude. Ovo je prvo izvješće o seroprevalenciji HEV-a u krava u Italiji, kojim se pružaju referentni podaci za daljnja istraživanja i kontrolu infekcije HEV-om u goveda.

Ključne riječi: HEV; virus hepatitisa E; protutijela; zoonoza; krava; ELISA 